the result of the co-operation of manufacturers in these three fields. Premises were fitted out as laboratories in Holloway, and research commenced under the directorship of T. Macara. In 1925 a further group of food manufacturers, mainly concerned with meat and fish products, set up the British Food Manufacturers' Research Association, at the same address and under the same director of research.

The two organizations continued to work in close association, but retaining their separate entities, until 1946, when amalgamation was decided on and plans drawn up for the construction of new laboratory premises at Leatherhead. In the meantime Mr. Macara had retired and had been succeeded as director of research by Dr. L. E. Campbell. At the first general meeting of the new Association, held in March 1947, Sir Frank Engledow was elected president, an office he still holds. The new laboratories were completed towards the end of 1950. Dr. Campbell relinquished his post in May of this year to join the United Nations Food and Agriculture Organization in Rome, and Dr. F. H. Banfield, who had been deputy director since 1948, took over as director of research.

On the opening day and on the day following, the laboratories were open for inspection by members of the Association and those interested in food research. Between four and five hundred visitors attended and studied the exhibits arranged in the laboratories to illustrate the work and scope of the Association. With a floor area of more than 19,000 sq. ft., the building has been planned on modern lines and the laboratories laid out and equipped in a most up-todate manner. There are general laboratories accommodating teams of laboratory workers, specialized laboratories such as that devoted to micro-biological investigations, a number of small laboratories housing one or two research workers, a large technical laboratory equipped for carrying out a range of factory processes on a small scale, and a spacious library containing some thousand books and ninety periodicals. The staff numbers about sixty, including some thirty graduates.

The work of the Association is balanced to cover the interests of the various groups of member firms. These groups include manufacturers of bakers' prepared materials, cocoa and chocolate, jam, margarine and compound cooking fats, meat and fish products, pickles and sauces, sugar confectionery, and various miscellaneous products, such as jelly tablets, starch and flour preparations, lemon curd, etc. Research being undertaken falls into two main categories : fundamental research, such as the investigations of problems connected with the rancidity of fats, and research into specific problems arising in connexion with particular manufacturing processes.

Of the general apparatus and equipment displayed on the two days that the laboratories were open, mention may be made of the exhibits designed to illustrate the various methods for the estimation of moisture in foods, the recording of the colour of foodstuff's, the measurement of the strength of gels, the measurement of the viscosity of chocolate and the use of refractometers in factory control. Among the demonstrations of application were the determination of air in margarine, the examination of the aerating properties of egg albumen and its substitutes, detection of formentation in foodstuffs, measurement of particle size with particular reference to particles of sugar in chocolate, and the study of the properties of starch gels and pastes. For the last-mentioned pur- pose two viscometers were shown, the Shirley con. sistometer and the corn industries viscometer. Another instrument recently installed is the Unicam photoelectric absorption spectrophotometer with application to the estimation of vitamin $A$ in marine animal liver oils. Other investigations being undertaken by the Association which were fully demonstrated to visitors were those in connexion with the effect of various methods of cooking on the digestibility of meat proteins, the shrinkage of meat and fish pastes in jars, the sedimentation of sauces, the preparation of gelatine from pork rinds, and the corrosion resistance of stainless steels and other alloys to the action of fruit juices, pickling brines and similar products.

In the micro-biological laboratory both the desirable and undesirable activities of micro-organisms in the preparation of manufactured foods are under investigation. Among desirable activities is the part played by bacteria in the curing of bacon in brine, and in the brining of vegetables. The growth of micro-organisms in pickles or canned goods or of mould on jams is, however, clearly undesirable. Strawberries preserved for jam-making in sulphur dioxide are sometimes subject to a breakdown as the result of the activity of enzymes, and investigation into the exact nature of this action is a subject of research.

A short account of the work of the Association would not be complete without mention of some of its other manifold activities. The suitability of fruits for commercial jam manufacture is one important item, and samples of jam prepared in the laboratories were displayed for inspection by visitors. In the entomological laboratory the means for the identification and control of pests liable to infect raw materials are under continual review, as are the methods of controlling rodents.

Analysis of foodstuffs plays a most important part in food manufacture. The extensive laboratory at Leatherhead devoted to this purpose is fully engaged in the testing of new official methods and the development of methods of analysis suitable for routine factory control. The part played by the Association in assisting members to conform to the standards demanded by modern conceptions of purity in foods, and with the food laws of the countries to which their goods are exported, is of the greatest help to members.

\section{GEOLOGY AND MINERAL RESOURCES IN THE BRITISH COLONIES}

THE first number of the second volume of the quarterly bulletin issued by the Mineral Re. sources Division, Colonial Geological Surveys, which has recently been published by H.M. Stationery Office, gives further evidence of the valuabie work being done by the expanded Geological Surveys of the Crown Colonies, and of the advantages gained from the limited measure of central organization which came into being after the Second World War.

Much space in this volume is devoted to an article on Sierra Leone, by J. D. Pollett, director of the Geological Survey Department of the Colony. The benefits of government-sponsored geological investigation are here illustrated particularly well. Although the first survey of the Colony, during 1918-21, 
failed to find any minerals of economic value, the investigations by Dr. N. R. Junner while director from 1928 onwards revealed high-grade iron ore, industrial diamond deposits, chromite, ilmenite and alluvial gold. Of these the first two mentioned have now reached major importance, more than $11,000,000$ tons of hæmatite and $10,000,000$ carats of diamonds having been exported during 1930-49.

Sierra Leone is mainly underlain by rocks of FreCambrian age, of which approximately half the total area is granite. This is intrusive into metamorphic rocks, the schists, gneisses and granulites of the Kasila Series, the Kambui Schists and the Marampa Schists. The granite is overlain by folded unfossili ferous sediments, the Rokell River Series, and these in their turn are covered unconformably with bedded arenaceous rocks believed to be equivalent to Gròs Horizonteaux of French Guinea, where fossil evidence indicates a Middle Silurian age. The primary iron-ore deposits consist of schistose specular hæmatite in the Marampa Schists, and banded iron-formation in the Kambui Schists. Near the surface, intense lateritic weathering has produced dense secondary hæmatite. The Colony peninsula is underlain by a banded noritic complex, including troctolite and gabbros, apparently lopolithic in form, and having other features in common with the great Bushveld lopolith in South Africa, including the presence of platinum.

Maps showing the geology and distribution of mineral localities on a scale of $1: 1,000,000$ accompany Mr. Pollett's article. Surveying of the Colony on the 1 inch : 1 mile scale has now begun with the expanded staff made possible by a grant from the Colonial Development and Welfare Scheme.

Under "Notes and Abstracts" an account is given of one of the first results of the recent effort to interest home university geological workers in Great Britain in problems of Colonial geology. A visit by Drs. J. Sutton and Janet Watson to Tanganyika to examine the granites and basement rocks is described in some detail ; Prof. W. Q. Kennedy visited Uganda.

The issue also includes articles on British Somaliland and on photogeology, and a laboratory report on glass sand from Nigeria. Reports from the various Geological Survey units indicate that geological work of considerable scientific interest as well as economic value is in progress in many parts of British Colonial territories.

K. C. DUNHaM

\section{PALATABILITY OF BIRDS' EGGS}

TN a paper submitted to the Zoological Society of 1 London (Proc. Zool. Soc. Lond., 121, Part I), Dr. Hugh Cott describes the results of an investigation into the relative acceptability of the eggs of twenty-five species of birds, belonging to ten orders, as illustrated by the feeding preferences of the hedgehog (Erinaceus europceus). In each of 332 experiments, one of four animals used as tasters was presented with a choice between two egg-samples. Possible disturbing factors such as differences in egg-size or shellcoloration, and those due to spatial arrangements of the samples, were eliminated by the use of raw egg, offered in equal quantities, and by the successive reversal in position of the egg-species matched within a particular group of experiments. or as offered to a particular experimental animal.

The reliability of the experimental method and the degree of consistency of hedgehog discrimination was checked by repetition experiments (between the same species-pair), both for the same and for different individuals; and by linking and overlapping experiments (between pairs of egg-species more or less widely separated in the edibility series). In general, the results show the hedgehog to be sensitive to differences in the relative palatability of the eggs offered, and to be consistent in its preferences and aversions; these show a broad agreement with those of man for the egg-species considered.

The experiments, which fall into groups carried out with sixty species-pairs, afford a basis for the arrangement of the several species in a provisional hierarchy of preference. The species fall broadly into three grades, and in descending order of acceptability are as follows : $(a)$ palatablo-kittiwake, eider, razorbill, gannet, domestic fowl, lapwing, common tern, coot; (b) intermediate-wood-pigeon, little owl, rook, puffin, magpie, jackdaw, hobby, kestrel, little grebe, buzzard, arctic tern, ringed plover ; (c) distastefulblackbird, chaffinch, sedge-warbler, whitethroat, linnet.

It is believed that the preferences shown by hedgehogs are likely to correspond with those of other eggeating animals, and that, within the limits of the series examined, they afford a satisfactory basis for consideration of the data in general terms. The wide range in specific edibility rating found to occur within certain orders suggests that relative acceptability may be largely independent of systematic status ; however, the low mean edibility rating for passeriform species indicates a trend towards nauseousness within this order. No close or obvious connexion has been traced between relative acceptability of the egg and feeding habits of the parent; nor is the quality of the egg at all constantly related to that of the flesh in the species examined.

Yet the experimental results also point towards ccrrelations between relative acceptability and various other ecological factors likely to influence susceptibility to attack by predators. First, there is a broad direct relationship between palatability of the egg and size of the parent. Secondly, the distribution, in terms of acceptability, of species having colonial and solitary nesting habits, respectively, shows a marked tendency for eggs of the former to be more, and those of the latter to be less, palatable. Thirdly, consideration of egg-palatability in relation to nest-site indicates that eggs laid in open nests in moderate growth or low herbage may be relatively distasteful as com. pared with those laid in various other situations. Fourthly, a general correlation is shown to exist between coloration of the shell and palatability of its contents. Broadly, cryptic eggs tend to belong to the higher edibility grades and distinctively marked eggs to the lower edibility grades.

Cott has also assessed the several species in terms of relative vulnerability, account being taken of such factors as size, weapons of defence, powers of offence, availability of the clutch, general habits, sociability and coloration. A general inverse correlation is shown to exist between the degree of vulnerability and that of acceptability - the most palatable eggs being those laid by non-vulnerable species, the most nauseous by those that are (otherwise) highly vulnerable. It is suggested that the facts point towards an adaptive interpretation of distastefulness in eggs, considered as a deterrent to attack ; and that the distinctive coloration of nauseous, but otherwise vulnerable, eggs may have a warning or recognitional value in relation to potential predators. 